(between 5000 and 50000 years). At the end of that time a clearly identifiable progeny species was established.

Paleontologists have long known that new species appear to come into the fossil record abruptly, with no apparent intermediates between the parental and progeny forms. There are two explanations for this. First, according to a classic model of evolutionary change, new species arise in small peripheral populations and their apparently sudden occurrence in the fossil record coincides with their reinvasion of the ancestral range. Second, because the transition period is short compared with the time resolution seen in much of the fossil record, the "instant" of speciation could be missed.

The "instant", however, is not missed in Williamson's study: it is documented with intermediates along the path from the older to younger species. At least as important as a record of intermediate forms, Williamson says, is a demonstration that, during the transition, the morphological variation of the species increases markedly. When the lake rose again, it was no longer cut off from other lake systems in the continent, and the ancestral species returned to Lake Turkana. This transgression of the lake coincides with the abrupt disappearance of the new species from the fossil record, a pattern of events thought to be the fate of new species in geographically isolated areas.
Williamson concludes in a Nature paper that speciation is a qualitatively different phenomenon from gradual, intraspecific microevolutionary change. He told Science that population geneticists have not addressed the question of stasis and that the genetics of developmental buffering is largely unknown.

\section{New Executive Elected}

The newsletter of the Geological Society of Trinidad and Tobago (GSTT) informs us that the new executive for 1981-82 will consist of the following:

President: W.A. Ali

1st Vice-President: T. Gabriel

2nd Vice-President: F. Hosein

Treasurer: V. Young On

Secretary: C.P. Telemagne

Asst. Secretary K.A. Merrick

It is interesting to note that this 46 -member society reports an impressive financial balance in October, 1981, of $\$ 51000$ (U.S.), most of which appears to have been earned as tuition fees charged for courses on seismic stratigraphy and plate tectonics run by the Society. The address for the GSTT is c/o Trinidad-Tesoro Petroleum Co. Ltd., Santa Flora, Trinidad and Tobago.

\title{
News from our Affiliates...
}

\section{- AIPEA}

The wide scope and interdisciplinary nature of clay mineralogy were the most striking features of the Seventh International Clay Conference, held under the auspices of the International Association for the Study of Clays (AIPEA) at Bologna and Pavia, Italy, in September, 1981. The research projects, discussed in three concurrent sessions and displayed on posters, ranged from the purely theoretical to the strictly applied.

About 380 scientists from 44 countries attended the conference, organized by the Italian group of AIPEA. The excellent facilities at the modern conference centre in Bologna and the special atmosphere of the historic towns, Bologna and Pavia, enhanced by Italian cuisine, all contributed to the success of the conference. Three guidebooks were compiled for pre-and post-conference field trips which led participants to central and southern Italy.

The scientific program was divided into seven general and seven special sessions, each introduced by an expert in the field. The occurrence and genesis of sepiolite-palygorskite sediments and deposits was the subject of a special seminar. Equilibria and kinetics of clays minerals in aqueous solution were discussed in a special joint session with IAGC, a sister will facilitate comparison of results obtained in different laboratories.

Plenary lectures dealt with the problems of clay mineralogy, colour in soils and sediments, the thermodynamic status of clay minerals and future trends in clay science. The plenary and introductory lectures and a selection of papers will be published by Elsevier Scientific Publishing Co. The study of clay minerals has reached a turning point with the development of various advanced analytical techniques. Nine papers on such techniques have been published in the "Developments in Sedimentology" series under the title "Advanced Techniques for Clay Mineral Analysis," edited by J.J. Fripiat (Elsevier 1981, Vol. 34).

The General Assembly unanimously adopted a council suggestion to establish an award in memory of W.F. Bradley, the distinguished crystallographer and clay mineralogist who died while he was president of AIPEA. Officers for 1981-85 are: L. Heller-Kallai (Israel, President); J.M. Serratosa (Spain, Vice-President); A.J. Herbillon (Belgium, Secretary-General); Dr. H. Kodama (Canada, Treasurer); and R.C. Mackenzie (Scotland, Past-president). The next conference will be held in Denver, Colorado, U.S.A., July 28-August 2, 1985.

L. Heller-Kallai AIPEA President

\section{News from IUGS National Adhering Bodies ...}

\section{- Argentina}

Dr. G.A. Chebli, president of the 1800 -member Asociacion Geologica Argentina, the national adhering body for IUGS, has announced the new officers of Argentina's National Committee for 1981-82.

President: G.A. Chebli

Vice-President: Carlos A. Cingolani

Secretary Miguel J. Haller

Treasurer: Guillermo E. Turazzini

Titular members: Juan V. Ploszkiewicz, Eduardo Espisua, Jorge O. Cangini
Alternate members: Milka K. de Brodtkorb, Eduardo Olivero

Dr. Chebli said that during its two-year term, the committee is interested in establishing closer contacts with IUGS. He suggested that the trimestrial journal, Revista de la Asociacion Geologica Argentina, which has been published for the past 35 years, would be an excellent way to provide information about the diverse activities of the IUGS commissions, committees and programs. The address for the Asociacion Geologica Argentina is Maipu 645, piso $1^{\circ}, 1006$ Buenos Aires, Republica Argentina. 